CZESŁAW PARTACZ

Politechnika Koszalińska, Koszalin

DOI : $10.14746 /$ rie.2017.11.9

\title{
Krytyczne spojrzenie na europejskie aspiracje Ukrainy i stanowisko Polski
}

Przemiany polityczne zapoczątkowane przez polską „Solidarność”, działania polityczne Michaiła Gorbaczowa oraz rozpad ZSRR na państwa narodowe, zjednoczenie Niemiec, rozwiązanie Układu Warszawskiego i wycofanie wojsk rosyjskich z Europy Środkowej, całkowicie zmieniło sytuację geopolityczną nie tylko tego regionu Europy, ale i świata. Rosja weszła w okres „smuty”, a Europa i świat przestały bać się jej nieobliczalnej, imperialnej polityki. Między Polską a Rosją wyrosły trzy nowe państwa: Białoruś, Litwa i Ukraina, co zwiększyło bezpieczeństwo RP. Świat stał się jednobiegunowy, z wyraźną dominacją Stanów Zjednoczonych. Państwa europejskie zaczęły redukować wydatki na zbrojenia i zmniejszać stany swoich wojsk. Niektórym politykom europejskim zaczęło się wydawać, że Rosja na zawsze straciła swoje imperialne zapędy.

Terytorium współczesnej Ukrainy nie powstało w wyniku działań ukraińskich sił politycznych czy wojskowych, ale decyzji rosyjskich. Nie ma ono wielowiekowej tradycji wspólnego życia w jednolitym organizmie państwowym, lecz jest tworem sztucznie połączonych co najmniej siedmiu różnych ziem nie tylko o odrębnej tradycji politycznej, historii, składu etnicznego, ale i mentalności oraz zróżnicowanej świadomości narodowej. Aby ten zlepek ziem i ludzi przekształcić w naród i w państwo XXI wieku, trzeba wysiłku i wielkiej spokojnej, pokojowej pracy co najmniej kilku pokoleń. Ale należy w tym miejscu zaznaczyć, że w oparciu o ideologię postkomunistyczną czy nacjonalistyczną dominującą na tych ziemiach, nie zbuduje się państwa przyjaznego ludziom i narodom sąsiedzkim.

Spełniły się marzenia i dążenia wielu pokoleń Ukraińców, dążących do budowy państwa, jak i podjętych w sprawie niepodległości działań i czynów, często niezgodnych z prawem. Powstała Ukrajinśka Samostijna, Sobornal Derżawa (USSD) o nazwie - Ukrajina. (Rychłowski, 1993, s. 58). Po upadku puczu Gennadija Janajewa w sierpniu 1991 r. i ogłoszeniu aktu niepodległości, na Ukrainie odżyły nadzieje na lepsze jutro bez komunizmu, wojen imperialnych i dominacji rosyjskiej. Ukraińcy uwierzyli w kuszącą wizję radykalnej poprawy sytuacji gospodarczej, po odłączeniu od imperium moskiewskiego. Nie zdawali sobie sprawy, że niepodległość to nie tylko akt prawny, ale wielopokoleniowy żmudny proces budowy i przekształcania społeczeństwa i państwa. Mieszkańcy Ukrainy przepojeni entuzjazmem, nie wiedzieli, jak bardzo trudna czeka ich droga.

${ }^{1} \mathrm{~W}$ miarę upływu lat, coraz więcej nacjonalistycznych działaczy ukraińskich stwierdza, że Ukraina jest nie do końca soborna, czyli zjednoczona. Wysuwają oni roszczenia terytorialne w stosunku do 19 powiatów współczesnej Polski, części Białorusi, Rosji, Rumunii, Mołdowy i Słowacji. 
Kiedy zarysowała się możliwość oderwania od Związku Sowieckiego, władze sowieckiej Ukrainy zadekretowały ogólnoukraińskie referendum na temat ogłoszenia niepodległości. Odbyło się ono 1 grudnia 1991 r. Postawiono na nim tylko jedno pytanie - „Czy zgadza się Pan/Pani z Aktem ogłoszenia niepodległości Ukrainy”. Tekst Aktu został przyjęty przez Radę Najwyższą Ukrainy 24 sierpnia 1991 r. i ogłoszony w biuletynie wyborczym. Głosujący opowiedzieli się za niepodległością. W referendum wzięło udział 31891742 (84,18\%) wyborców, z których 28804071 (90,92\%) głosowało ,za"2.

Wyniki referendum i powstanie nowych państw we Wschodniej Europie nie tylko kompletnie zaskoczyło, a nawet poirytowało wielu polityków i analityków politycznych. Z postsowieckiego zamętu wyłoniła się nikomu nieznana do tej pory Ukraina, Białoruś i wiele innych państw. Nazajutrz po referendum, jako pierwsza niepodległość Ukrainy uznała Polska, później Węgry i Kanada. Ta emocjonalna, przedwczesna decyzja polska była nieprzemyślana i z perspektywy czasu należy uznać ją za duży błąd polityczny. Po wizycie w Kijowie w dniach 18-19 grudnia sekretarza stanu Jamesa Bakera, Stany Zjednoczone uznały Ukrainę 25 grudnia. Dopiero po tej decyzji, nowe państwo uznane zostało przez większość krajów Zachodu.

Nowe państwo miało wszelkie podstawy do samodzielności. Posiadało rozległe terytorium, liczną ludność o wysokim poziomie wykształcenia obywateli, bogactwa naturalne, największe na świecie zasoby czarnoziemów i niezbyt nowoczesny przemysł oraz korzystne położenie geostrategiczne. Były to idealne warunki, aby stało się ważnym i samodzielnym podmiotem, a nie marginalnym przedmiotem polityki europejskiej. Na perspektywę ukraińskiego derżawotworennija patrzono na Ukrainie z dużym optymizmem. Inaczej to wyglądało z perspektywy zachodu Europy i Stanów Zjednoczonych. Zbigniew Brzeziński uznał proklamowanie niezależności Ukrainy w 1991 roku, za jedno z trzech najważniejszych wydarzeń geopolitycznych XX wieku (Brzeziński, 1992). Zaliczył do nich również rozpad imperium austro-węgierskiego i podział Europy na rzece Łabie na dwa bloki w 1945 roku. Po proklamowaniu niepodległości, Ukraina stała się jednym z sześciu (Rosja, Niemcy, Wielka Brytania, Włochy i Francja) największych krajów Europy. Ukraińcy byli świadkami burzenia imperium sowieckiego bez przelewu własnej krwi, strat terytorialnych i własnego wysiłku. Wbrew temu co dzisiaj mówi i pisze większość ukraińskich historyków i polityków, przyszłość ich państwa wypracowana została w Moskwie. Czas nie zweryfikował tego stwierdzenia. Praktyka ukraińskiego życia politycznego i gospodarczego została zdominowana przez oligarchów, postkomunistów i nacjonalistów, co doprowadziło do dzisiejszej zapaści państwa.

Po proklamowaniu niepodległości sytuacja na Ukrainie wyglądała bardziej optymistycznie niż w innych, byłych republikach sowieckich. W przededniu rozwiązania Związku Sowieckiego, eksperci Deutsche Bank oceniali, że Ukraina ma największe szanse na szybkie i w miarę komfortowe przejście do systemu demokratycznego jak i wolnego rynku. Prognoza ta, spopularyzowana przez media, wpłynęła pozytywnie na wynik referendum. W następnych latach Ukraińcy starali się wypełnić treścią otrzy-

225 lat temu 90,92 proc. Ukraińców w referendum potwierdziło niepodległość swojego państwa Читайте більше тут: http://zik.ua/pl/news/2016/12/01/25_lat_temu_9092_proc_ukraicw_w_referendum_potwierdzio_niepodlego_1001017,27.05.2017. 
maną od losu niepodległość. Wprowadzono namiastkę własnej waluty, czyli kupony i przystapiono do formowania narodowej armii. Ale cała machina państwa funkcjonowała dalej po sowiecku. W wielu obszarach przetrwało to do dzisiaj.

Mimo wielu decyzji utrwalających suwerenność państwa, przez następne dwadzieścia lat Ukraina była postrzegana jako twór sztuczny i nieobliczalny, a może nawet sezonowy, siedzący okrakiem na granicy Wschodu i Zachodu. Wizerunek ten, kreowany w dużej mierze przez propagandę rosyjską, był również wynikiem niekonsekwentnej polityki władz ukraińskich w wielu kwestiach, głównie denuklearyzacji. Po rozpadzie Związku Sowieckiego, na terytorium Ukrainy pozostały znaczne zasoby broni atomowej. Zgodnie z ustaleniami szczytu w Ałma-Acie z grudnia 1991 roku, broń ta w całości miała być przekazana Rosji, jako spadkobierczyni ZSRR. Jednakże wiosną 1992 roku prezydent Aleksander Krawczuk wstrzymał demontaż głowic i ich wywóz do Rosji. Ukraińcy byli zachwyceni tą decyzją, a państwa Zachodu zaszokowane. Ukraina znalazła się w międzynarodowej izolacji. Dopiero po podpisaniu w grudniu 1994 roku układu ukraińsko-rosyjsko-amerykańskiego (tzw. memorandum budapeszteńskie), nastapiła dezatomizacja Ukrainy. Był to wielki błąd polityczny władz tego państwa. Ukraina zamieniła broń atomowa, na nic nie warte papierowe gwarancje niepodległości i integralności, co jest dzisiaj jaskrawo widoczne.

Stosunki Ukrainy z Unią Europejską - zostały nawiązane w 1994 r. Już 14 czerwca 1994 r. podpisano układ o partnerstwie i współpracy z Ukrainą, a 28 listopada Rada Unii Europejskiej przyjęła stanowisko określające cele i priorytety tej współpracy. Pierwszy szczyt UE-Ukraina odbył się we wrześniu 1997 r. w Kijowie. Prezydent Leonid Kuczma potwierdził dążenie Ukrainy do stowarzyszenia z Unia, zgodnie z umową o partnerstwie i współpracy podpisaną z Europejską Wspólnotą Węgla i Stali, dzięki której umożliwiony został handel ukraińską stala. Innym rezultatem tego szczytu było zniesienie obowiązku wizowego dla posiadaczy ukraińskich paszportów dyplomatycznych w państwach członkowskich UE. Kijów deklarował chęć przystapienia do UE najpóźniej do 2011 r. (EU-Ukraine). Układ o partnerstwie i współpracy wszedł w życie 1 marca 1998 r. Ustanowił on , Radę Wspótpracy UE-Ukraina", która zebrała się po raz pierwszy 9 czerwca 1998 r. Rezultatem spotkania było przyjęcie planu współpracy na lata 1998-1999. Na szczycie w $1998 \mathrm{r}$. w Wiedniu zadeklarowano strategiczne partnerstwo i zbieżność dążeń, interesów i wyznawanych wartości. Natomiast na trzecim szczycie w lipcu 1999 r. rozpoczęto prace nad przystąpieniem Ukrainy do Światowej Organizacji Handlu (WTO) oraz ustanowieniem strefy wolnego handlu między Ukrainą i UE (EU-Ukraine). W dniu 11 grudnia 1999 r. władze UE przyjęły strategię wobec Ukrainy, podkreślając znaczenie jej wejścia na drogę reform demokratycznych. Unia przywiązywała dużą wagę do proeuropejskiej orientacji państwa ukraińskiego. Strategia była przewidziana na 4 lata z możliwością dalszego jej przedłużenia. Określiła też cele strategiczne, jakie UE stawiała wobec Ukrainy:

- wsparcie demokracji i wolnego rynku;

- umacnianie bezpieczeństwa i stabilności w Europie i na świecie;

- współpraca polityczna, w szczególności dotycząca zbliżania Ukrainy do Unii;

- współpraca gospodarcza i kulturalna oraz wymiaru sprawiedliwości i spraw wewnętrznych. 
Do realizacji wspólnej strategii postanowiono zaprosić także państwa kandydujące wówczas do Unii (m.in. Polskę, Węgry i in.). Uzgodniono udzielenie pomocy w ich integracji z europejską gospodarką. Omówiono również kwestie związane z ochroną środowiska, energetyką i bezpieczeństwem atomowym.

Na czwartym szczycie z września 2000 r., UE potwierdziła swoje poparcie dla reform na Ukrainie i dążenia do stowarzyszenia z UE. Wspólne oświadczenie podpisali: przewodniczący Komisji Europejskiej Romano Prodi i prezydent Francji Jacques Chirac oraz Leonid Kuczma. Z kolei we wrześniu 2001 r. i w lipcu 2002 r. na szczytach w Jałcie i Kopenhadze, przywódcy UE apelowali do Ukrainy o przestrzeganie zasad demokracji, o których łamanie opozycja oskarżała Leonida Kuczmę. Uzgodniono, że Unia będzie w tym celu wspomagać Ukrainę w działaniach w zakresie wymiaru sprawiedliwości i respektowania wolności. Na drugim z tych spotkań wspólnie potwierdzono, że Ukraina powinna przystosować swój system prawny i standardy do norm unijnych, w zamian za co UE wprowadzi ułatwienia dla swoich i ukraińskich obywateli przy przekraczaniu wspólnej granicy. W czerwcu 2002 r. Rada Europejska na spotkaniu w Sewilli ustanowiła mechanizm konsultacji i współpracy z Ukrainą w zakresie reagowania kryzysowego. Wówczas rozpoczęto wspólne konsultacje i współpracę podczas misji policyjnej w Bośni i Hercegowinie. Na siódmym szczycie UE-Ukraina w Jałcie z października 2003 r., w czasie kiedy Wspólnota Europejska przygotowywała się na pierwsze rozszerzenie na Wschód, Bruksela nie zaoferowała członkostwa w Unii Ukrainie, lecz tylko usankcjonowanie statusu kraju należącego do programu Europejskiej Polityki Sąsiedztwa. Kuczma wówczas stwierdził, że Ukraina chciała przyjąć plany restrukturyzacji gospodarki, dzięki której mogłaby osiagnąć status gospodarki rynkowej. Ale były to zamiast konkretów tylko czcze obietnice. Ukraiński prezydent poruszył również kwestię uproszczenia przepisów wizowych dla obywateli Ukrainy (UE-Ukraine, 23.02.2013).

Od czasu przystapienia Polski do Unii Europejskiej władze polskie starały się reprezentować we Wspólnocie interesy Ukrainy. Polska wielokrotnie podejmowała starania o zintensyfikowanie debaty nad możliwością przyjęcia Ukrainy do Unii Europejskiej (Barburska, 2006, s. 60-61). Czasami wywoływało to nawet irytację unijnych partnerów. W roku 2004 ówczesny przewodniczący Parlamentu Europejskiego Josef Borrell powiedział: „Polsce jest bliżej do Ukrainy niż do innych członków Unii” (Kaminski, Sołtyk, 2005).

W okresie pomarańczowej rewolucji w 2004 r., Unia popierała opozycję i pomagała utworzyć ukraiński okragły stól, dzięki któremu powtórzono drugą turę wyborów prezydenckich. W styczniu 2005 r. pozytywnie przyjęto oświadczenie Ukrainy o ubieganiu się o członkostwo w UE, jednak nie przyznano jej statusu kraju kandydującego. Dopiero 21 lutego 2005 r. włączono Ukrainę do Europejskiej Polityki Sąsiedztwa, jako partnera priorytetowego. Po objęciu rządów przez Wiktora Juszczenkę, który został wyniesiony na fali Pomarańczowej Rewolucji, wśród Ukraińców zostały rozbudzone nadzieje na członkostwo we Wspólnocie Europejskiej. Ale pod koniec 2005 roku UE wysyłała sprzeczne komunikaty. W październiku 2005 r. przewodniczący Komisji Europejskiej José Manuel Barroso stwierdził, że przyszłość Ukrainy jest w UE. Jednakże 9 listopada 2005 r., Komisja Europejska w nowym dokumencie strategicznym zasugerowała, że ówczesny program rozszerzenia 
(Chorwacja i w przyszłości inne kraje byłej Jugosławii) może blokować możliwość przyszłej akcesji Ukrainy, Armenii, Białorusi, Gruzji i Mołdawii. Komisarz Europejski ds. Rozszerzenia Olli Rehn powiedział, że UE powinna unikać nadmiernej ekspansji, dodając, że program rozszerzenia był już zbyt duży. Zapewne związane to było $\mathrm{z}$ bardzo niskim poziomem rozwoju i dochodu narodowego w tych krajach. Zamożne państwa UE nie chciały dokładać finansowo do krajów tak rażąco biednych, w których decydujący głos w gospodarce miała wąska grupa oligarchów. W dniu 1 grudnia 2005 r., na dziewiątym szczycie UE-Ukraina w Kijowie, podpisano memorandum dotyczące energetyki. Ustalono $\mathrm{w}$ nim strategię integracji ukraińskiego i unijnego rynku energii, formułując „mapę drogową”, obejmującą kwestie bezpieczeństwa nuklearnego, energetycznego, poprawy standardów ekologicznych, integracji rynków i zapewnienie samowystarczalności energetycznej. We wrześniu 2006 r. osiagnięto porozumienie dotyczące wykorzystania funduszy Europejskiego Banku Inwestycyjnego i Europejskiego Banku Odbudowy i Rozwoju do wspierania ukraińskiej energetyki. Do końca 2006 r. z programu TACIS finansowano także badania nad reformą ukraińskiego systemu przesyłu gazu ziemnego. W międzyczasie, na 10. Szczycie Ukraina-UE, który odbył się w październiku 2006 w Helsinkach, przedstawiciele UE zadeklarowali, że Europa jest gotowa do rozpoczęcia procesu negocjacji o utworzeniu strefy wolnego handlu między Ukrainą a UE, a także omówienie nowej umowy między podmiotami. Strony omówiły również porozumienia w sprawie uproszczenia przepisów wizowych, współpracy w sektorze energetycznym oraz wspólną politykę zagraniczną i bezpieczeństwa.

Kolejne negocjacje z marca 2007 r. miały na celu wypracowanie i podpisanie nowego układu, który miał pomóc zbliżyć się Ukrainie do UE. Z kolei w lutym 2008 r. rozpoczęto rokowania dotyczące strefy wolnego handlu, a prezydent Wiktor Juszczenko podpisał 5 lutego 2008 r. protokół o przystąpieniu Ukrainy do tej strefy. Ukraina stała się w maju 2008 r. członkiem tej ważnej organizacji międzynarodowej (Zięba, 2007, s. 167). W czerwcu 2007 r. obie strony podpisały umowę o liberalizacji systemu wizowego, ponieważ Ukraina negatywnie odczuła reperkusje związane z poszerzeniem strefy Schengen o kraje Europy Środkowej. Podczas 12. szczytu Ukraina-UE w Paryżu poinformowano o rozpoczęciu negocjacji nad umową stowarzyszeniową, a z kolei w październiku 2008 r. rozpoczęto rozmowy dotyczące wprowadzenia systemu bezwizowego (Haliżak, Kuźniar, 2009, s. 210).

Mimo widocznego postępu w stosunkach z krajami UE, przeważająca większość z nich uważała, iż Ukraina nie jest przygotowana gospodarczo i politycznie na przystąpienie do struktur Unii, ponieważ nie spełniała kryteriów zawartych w mechanizmie kopenhaskim. W związku z tym UE poparła rozwijanie współpracy w ramach polskoszwedzkiej inicjatywy Partnerstwa Wschodniego z maja 2008 r. W tym czasie sytuacja wewnętrzna na Ukrainie uległa destabilizacji, co nie wpłynęło korzystnie na relacje Kijowa z UE. W wyniku wewnętrznych sporów i walk partyjnych doszło do nieudanej próby odwołania w dniu 11 lipca 2008 r. przez Partię Regionów rządu Julii Tymoszenko. Wojna rosyjsko-gruzińska z sierpnia 2008 roku również negatywnie wpłynęła na wewnętrzną politykę Ukrainy. Część społeczeństwa i klasy politycznej poparła Rosję, a druga część Gruzję. W trakcie rządów ,pomarańczowej koalicji” przedmiotem sporów stały się relacje gazowe, w wyniku czego Moskwa zmusiła Ukrainę do akceptacji 
podwyżki cen gazu. W grudniu 2009 r., na 13. szczycie UE-Ukraina strony uznały, że większość prac nad umową stowarzyszeniową zostało zakończonych. José Manuel Barroso wyraził nadzieję, że negocjacje w sprawie stowarzyszenia mogą zostać zakończone do końca 2010 r. Ale przeszkodą stała się zmiana polityki po wyborach prezydenckich ze stycznia $2010 \mathrm{r}$. Zwyciężył w nich Wiktor Janukowycz, stojący na czele antyunijnej i prorosyjskiej Partii Regionów. Wkrótce Rada Najwyższa wyraziła wotum nieufności dla rządu Julii Tymoszenko, a 11 marca 2010 r. parlament rozwiązał rząd i zatwierdził nowy gabinet premiera Mykoły Azarowa (Ukraina: koalicja, z 11.03.2010).

Od czasu uzyskania przez Ukrainę niepodległości, władze Polski aktywnie nie tylko popierały przemiany polityczne $\mathrm{w}$ tym państwie, ale też próbowały zmniejszyć w nim wpływy rosyjskie. Wskazuje na to cała polityka władz państwa polskiego wobec zachodzacych zmian. Polska wspierała nawet organizacje nacjonalistyczne i antypolskie o ile były one jednocześnie antyrosyjskie. Władze polskie nie reagowały na fakt, że ukraiński parlament uznał zbrodniarzy UPA za bohaterów walki o niepodległość Ukrainy i zapowiedział ściganie osób podważających „dobre imię” banderowców (Komorowski w gazecie, 5.05.2015). Z dużym prawdopodobieństwem można założyć, iż zorganizowana obecnie w duchu integralnego nacjonalizmu Ukraina, może w najbliższym czasie okazać się dużym zagrożeniem dla sąsiadujących z nią państw, głównie Polski i Węgier (Grott, 2015).

Wspierając bezwarunkowo i jednostronnie Ukrainę, Polska może bardzo się przeliczyć, bo przecież ideologia i tradycja Organizacji Ukraińskich Nacjonalistów (OUN), popierane i propagowane przez organy państwa są coraz silniejsze w dużej części społeczeństwa ukraińskiego. Prawdziwie demokratyczna formacja polityczna dotychczas nie powstała w tym państwie. Wpływy ideologii nacjonalistycznej są najbardziej widoczne w zachodnich i centralnych obszarach państwa; a więc w najbliższym sąsiedztwie Polski (Grott), co jest w dalszej perspektywie niebezpieczne. Obecnie coraz bardziej rozpowszechnione jest przeświadczenie, że czasy wojujących, szowinistycznych nacjonalizmów już się skończyły, a doświadczenia ostatniej wojny światowej wytworzyły klimat dla idei związanych z zasadami tolerancji i poszanowania wartości humanistycznych. Ale zasada ta nie obowiązuje na terenach, na których właściwie nigdy wcześniej nie było demokracji, lecz cywilizacja bizantyńsko-turańsko-kozacka, a pierwotna anarchia i samodzierżawie zostało zastapione przez komunizm, a obecnie nacjonalizm w wydaniu raczej „,neobanderowskim”. Ten system, oddziałując coraz silniej przez ostatnie dwadzieścia pięć lat, ukształtował mentalność społeczną mieszkańców zachodniej i częściowo środkowej Ukrainy, a wyznawane przez niego negatywne i antyhumanistyczne wartości, nie tylko są żywe, ale rosną w siłę wbrew liberalnym trendom europejskim. W dodatku zapomniano zupełnie o etyce. W zachodnich obwodach Ukrainy, czyli na byłych polskich Kresach Wschodnich, odbudował się ukraiński integralny nacjonalizm, w postaci różnorodnych organizacji i partii „neobanderowskich". Ostatnie lata wykazuja, że obecnie skrajny nacjonalizm ukraiński jest dla tego społeczeństwa i państwa żywą ideologią, w dodatku propagowaną przez państwo. Wypełnia on lukę po zbankrutowanym komunizmie sowieckim (Grott, 2015), ale jest niebezpieczny tak dla Ukrainy, jak i dla krajów ościennych. W wyniku wielu działań, szczególnie diaspory ukraińskiej z Zachodu i rosyjskiej agentury wpływu, 
Ukraina stała się skansenem przebrzmiałych, skompromitowanych ideologii i nurtów politycznych oraz propagowanej przez państwo fałszywej historii, będącej mistrzynią fałszywej polityki. W państwie ukraińskim, mimo pozornie demokratycznego (w rozumieniu zachodnim) systemu politycznego, koegzystują stare autokratyczne metody i pseudodemokratyczne zasady (Kapusniak, 2007, s. 19). Metody te są stosowane bez względu na to, jaka opcja polityczna sprawuje władzę.

To co może niepokoić mieszkańców państw sąsiednich to fakt, iż władze Ukrainy są zdominowane przez oligarchów, z którymi współpracują środowiska nacjonalistyczne. Nastroje nacjonalistyczne są silne zwłaszcza na ziemiach tzw. zachodniej Ukrainy, natomiast na wschodzie skojarzenia z Banderą i jemu podobnymi budzą negatywne emocje. Może to spowodować trwały rozpad tego kraju. Według ks. Tadeusza Isakowicz-Zaleskiego jest to najgorszy, chociaż realny, scenariusz: „Gdyby doszło do rozpadu Ukrainy [...], to nie będziemy graniczyli z wielonarodowościową i wielokulturową Ukraina, tylko z [...] Hałyczyną, Zachodnią Ukraina, gdzie ruch banderowski będzie absolutnie dominującą siłą" (Isakowicz-Zaleski, 2014).

Powstanie za granicą południowo-wschodnią biednego państwa halickiego o ideologii „neobanderowskiej”, byłoby niebezpieczne dla Polski, Słowacji i Węgier, tym bardziej, iż nacjonaliści głoszą potrzebę rewizji granic na korzyść Ukrainy.

O stosunku do innych narodowości, w tym Polaków i Polski, nielicznej ale głośnej partii Prawego Sektora, świadczą wypowiedzi jednego z przywódców tej organizacji - Andrija Tarasenki udzielone w 2104 r. dziennikowi „Rzeczpospolita”. Twierdzi on, że mordowanie Polaków przez OUN nie było ludobójstwem, ale jedynie walką z okupantem przy pomocy radykalnych środków. Poza tym według niego Polska powinna oddać Ukrainie Przemyśl i kilkanaście okolicznych powiatów (Bielacki, 2014). Wypowiedź ta miała miejsce w czasie zamieszek na Majdanie. W wyborach parlamentarnych na Ukrainie z 26 października 2014 r. zwyciężył Front Ludowy premiera Arsenija Jaceniuka, uzyskując 22,14\% głosów („Neesweek”, 12.12.2014). Formalnie jest to proeuropejska partia liberalno-demokratyczna (Olszański, Ukraines, 12.12.2014). Jednak w rzeczywistości tworzą ją ludzie w dużym stopniu związani z banderowskimi tradycjami oraz z oligarchami. Poza Jaceniukiem jednym z czołowych polityków Frontu Ludowego jest między innymi Andrij Parubij, współzałożyciel Socjal-Narodowej Partii Ukrainy, przemianowanej później na Ogólnoukraińskie Zjednoczenie "Swoboda", nawiązujące do przedwojennego nacjonalizmu (Czech, 2014). Założenia „Swobody” zmierzają do uznania weteranów UPA za bojowników o wolność Ukrainy, derusyfikacji państwa, wprowadzenia ustawy o obronie języka ukraińskiego czy pozbawienia obywatelstwa cudzoziemców (Witryna, 2010).

Spośród państw Europy Środkowo-Wschodniej nacjonalistyczne podejście obecnych władz Ukrainy wydaje się być najmniej zauważalne w Warszawie. Należy stwierdzić, że polska polityka zagraniczna prowadzona jest według dziwnych kryteriów, zwalczając „reżimy niedemokratyczne” - Rosji czy Białorusi, wspomaga ustroje oligarchiczne na Ukrainie, w Gruzji czy Azerbejdżanie. Zaangażowanie na rzecz Ukrainy wymaga głębszego przemyślenia, a nie brania pod uwagę oderwanych od rzeczywistości pomysłów Jerzego Giedroycia czy interesów Waszyngtonu. Nikt nie podważa zasadności pomocy Ukrainie w jej nieudolnej i oligarchicznej transformacji oraz utrzymaniu niezależności tego państwa. Poparcie dla Ukrainy nie może jednak 
być bezwarunkowe i pomijać istotne uwarunkowania wewnętrzne, które mogą zadecydować o jego przyszłości. Należy do nich:

1) przewlekły stan braku konsolidacji ustrojowej;

2) trwałe tendencje separatystyczne na wschodzie i zachodzie kraju;

3) coraz bardziej ograniczony charakter władzy centralnej;

4) umacnianie wpływów oligarchicznych i mafijnych;

5) permanentny stan zapaści gospodarczej;

6) różnice polityczne (nacjonalizm i komunizm) i rozłamy w obozie rządzącym;

7) brak krytyczno-realistycznego spojrzenia na historię stosunków z ościennymi krajami, a szczególnie relacji ukraińsko-polskich, ukraińsko-rosyjskich i ukraińskowegierskich (Stolarczyk, 2014).

Trwała wrogość w stosunkach ukraińsko-rosyjskich, nie może wpływać na konfrontację w relacjach polsko-rosyjskich. Polityka zagraniczna Polski powinna skupiać się na potrzebach i korzyściach dotyczących Polski i jej obywateli, a nie Ukrainy. W dodatku Ukraina nie ma najmniejszego zamiaru stosować w stosunku do Polski polityki wzajemności, co, niestety, akceptują politycy polscy. Wymierne straty gospodarcze będące wynikiem włączania się w konflikt z Rosją, ponosi głównie polska gospodarka. Polacy zapewne w dłuższej perspektywie upomną się o swoje interesy. Bezkrytyczna orientacja na Ukrainę jest niebezpieczna z dwu powodów:

1) nie wynika $z$ diagnozy własnych interesów, jest natomiast działaniem niekorzystnym dla Polski a korzystnym dla globalnych interesów USA, Niemiec i Izraela;

2) nie ma żadnych gwarancji, że Ukraina ze względu na rozrost ideologii nacjonalistycznej, nie stanie się w przyszłości państwem antypolskim.

Przestrzegają przed tym badacze polityki krajów Europy Wschodniej, ale nie znajduje to żadnego zrozumienia u polityków polskich. Musimy w tym miejscu stwierdzić, iż władze wielu krajów UE uważaja, że Ukraina nie ma prawa podejmować działań politycznych i militarnych, które zagrażają interesom innych państw (Bieleń, 2014, s. 64).

Zupełnie inaczej wydarzenia na Majdanie i zmiana władzy na Ukrainie zostały odebrane w Budapeszcie. Węgrów zaniepokoiła podjęta w zaledwie kilka godzin po obaleniu Janukowycza decyzja o likwidacji ustawy językowej. Władze węgierskie oficjalnie niepokoją się o 150 tys. mniejszość węgierską zamieszkującą Zakarpacie, ze względu na działalność ukraińskich organizacji nacjonalistycznych takich jak Swoboda czy Karpacka Sicz. Przedstawiciele tych organizacji wielokrotnie bezcześcili węgierskie i polskie miejsca pamięci (Gizinski, 2016). Z takimi dążeniami trudno będzie Ukrainie wejść w struktury europejskie.

Olbrzymią rolę w relacjach UE-Ukraina odegrało aresztowanie Julii Tymoszenko. Prezydent Ukrainy Wiktor Janukowicz, który reprezentował opcję prorosyjska, doprowadził do wszczęcia postępowania karnego przeciwko byłej premier. Związane to było z zarzutami ewidentnej defraudacji podczas podpisania umowy gazowej z Rosją. Postępowania karne wytoczone Julii Tymoszenko i członkom jej rządu stały się przedmiotem zainteresowania mediów europejskich i rządów. Parlament Europejski skrytykował władze ukraińskie i wezwał do zapewnienia niezależności i bezstronności w procesach sądowych. Sprawa Tymoszenko stała się z pozoru główną przeszkodą, a w zasadzie pretekstem do osłabiania więzi Ukrainy z Unią Europejską. Następny, bo 
14 szczyt UE-Ukraina odbył się w listopadzie 2010 w Brukseli. Wykazał on, że władze Unii zaczęły po tym procesie sądowym negatywnie odbierać dążenia Ukrainy do podpisania umowy stowarzyszeniowej. Oficjalnie chodziło o reorientację ukraińskiej polityki zagranicznej. Napięta atmosfera była widoczna na 15. szczycie UE-Ukraina, odbytym w grudniu 2011 roku w Kijowie. Wówczas obłudnie ogłoszono, że podpisanie umowy stowarzyszeniowej będzie zależeć od stanu rozwoju demokracji na Ukrainie. Mimo tych przeciwności, w 2012 roku rozpoczęto negocjacje nad podpisaniem umowy stowarzyszeniowej. Po rocznych negocjacjach, został przygotowany projekt reform ukraińskiego prawa. Przeciw planom ukraińskim wystapiła wielokierunkowo Rosja. Aby wyjść z impasu, UE wysłała do Kijowa swoich specjalnych wysłanników. Był to Pat Cox, były przewodniczący Parlamentu Europejskiego V kadencji i były prezydent Polski, Aleksander Kwaśniewski. Ich celem było uwolnienie Julii Tymoszenko i doprowadzenie do podpisania umowy stowarzyszeniowej. Zwrócili się oni 4 października 2013 r. do ukraińskiego prezydenta z prośbą o ułaskawienie byłej premier. Jakby w odpowiedzi i pod naciskiem Moskwy, 21 listopada 2013 r. rząd Ukrainy ogłosił zawieszenie procesu przygotowań do podpisania umowy o stowarzyszeniu i strefy wolnego handlu z Unią Europejską. Podczas III szczytu Partnerstwa Wschodniego w Wilnie 28-29 listopada 2013 roku władze Ukrainy zawiesiły podpisanie umowy stowarzyszeniowej z UE (Dokumenty, 2014). Ale prezydent Wiktor Janukowycz, w przeciwieństwie do przywódców Gruzji i Mołdawii umowy nie podpisał. Ta decyzja była podsumowaniem Partnerstwa Wschodniego lansowanego przez polską dyplomację. Spotegowała ona antyprezydenckie nastroje w społeczeństwie ukraińskim, głównie wśród młodzieży. Ukraińska policja już 30 listopada 2013 r. brutalnie rozpędziła demonstrantów zgromadzonych w Kijowie na Placu Niepodległości. Akcję potępiły m.in. Stany Zjednoczone i władze Unii Europejskiej. Protesty przeciwko władzy Janukowycza przerodziły się w rewolucję na Placu Niepodległości w Kijowie, a później w innych miastach Ukrainy. W Dniu Jedności ${ }^{3}$ Ukrainy 22 stycznia 2014 roku, zginęło od broni palnej pierwszych 5 demonstrantów (Korniejenko, 2014, s. 18). Do następnej masakry doszło 20 lutego 2014 roku. Dr Iwan Kaczanowśkyj z Uniwersytetu w Ottawie, twierdzi, że tę masakrę na Majdanie Niepodległości, w której zginęło ponad 100 osób z tzw. „niebiańskiej sotni” oraz kilkunastu policjantów, dokonali sami opozycjoniści z Prawego Sektora (Schwertner, Ivan Kaczanowski, 2015). Za tą prowokacją stali skrajni nacjonaliści oraz oligarchowie.

Wydarzenia Euromajdanu doprowadziły do zamachu stanu, w wyniku którego w lutym 2014 r. władzę utracił Wiktor Janukowycz. Natychmiast po jego ucieczce do Rosji, nowy rząd Arsenija Jaceniuka przeforsował w Radzie Najwyższej uchylenie ustawy o zasadach polityki językowej z 3 lipca 2012 roku. Była to pierwsza decyzja jaką podjęli ukraińscy parlamentarzyści po zmianie władz w Kijowie (Junko, 2017). Wspomniana ustawa chroniła języki mniejszości etnicznych i regionalnych. W sytuacji, kiedy znaczna część obywateli Ukrainy posługuje się na co dzień językiem rosyjskim, anulowanie tej ustawy miało charakter destrukcyjny a nawet prowokacyjny. Ustawa ta zapewniała ,językom regionalnym i mniejszościom narodowym” rolę równoległego

${ }^{3}$ Jest to święto zjednoczenia Ukraińskiej Republiki Ludowej i Zachodnioukraińskiej Republiki Ludowej 22 stycznia 1919 roku. Święto to ustanowił prezydent Leonid Kuczma dekretem z dnia 21 stycznia 1999 r., jako Deń Sobornosti Ukrajiny. 
języka urzędowania władz publicznych i samorządowych w tych regionach, w których co najmniej 10\% mieszkańców wyrazi taką wolę w formie petycji (Olszański, 2015). Uchylenie tej ustawy przez czynniki skrajnie nacjonalistyczne wywołało gwałtowny sprzeciw liczącej 12 milionów ludności rosyjskojęzycznej ze wschodu i południa Ukrainy i było zapalnikiem dla wybuchu jej separatystycznego buntu.

Aby Ukraina jako państwo była silna i utrzymała niepodległość, potrzebna jest zgoda społeczna do istnienia wspólnoty politycznej i jej tożsamości. Podziały polityczne na różne partie są sprawą naturalną i z pewnością będą na Ukrainie zwolennicy i przeciwnicy ugrupowań o charakterze narodowym. Polska powinna w tej sytuacji doradzać Ukrainie, że jej polityczna przyszłość nie może być zbudowana na tradycji OUN-UPA, bo prowadzi to do podziału tworzącego się narodu i wywołuje perturbacje w stosunkach międzynarodowych. Droga do demokratycznej Ukrainy wiedzie poprzez wyjście z pułapek przeszłości z czasów II wojny światowej. Ukraina współczesna musi stanąć na własnych nogach i odciąć się jednocześnie od banderowskiej i sowieckiej przeszłości. Niestety, nacjonaliści znajdujący się już we władzach Ukrainy sądzą inaczej. Ich celem jest narzucenie całej ludności Ukrainy własnej, zafałszowanej wersji historii nowożytnej, a szczególnie II wojny światowej. Nacjonaliści, którzy tak naprawdę mają swoje główne ośrodki ideologiczne w Kanadzie, Stanach Zjednoczonych, Niemczech i w Polsce, chcą wygrać wojnę, którą przegrali 70 lat temu. Prawda jest taka, że 15-20\% ukraińskiego społeczeństwa chce narzucić pozostałej części swoją ideologię i zmusić do przyjęcia fałszywego poglądu, iż tylko ci „wybrani walczyli” z Niemcami o Ukrainę, a pozostali robili to dla Rosji. Nie ma to nic wspólnego z prawdą historyczną i jest najbardziej szkodliwe dla Ukrainy.

Przyjęty przez Najwyższą Radę, w trakcie wizyty prezydenta Bronisława Komorowskiego na Ukrainie, „kombatancki” pakiet prawny, ostatecznie porządkuje „ład moralno-polityczno-ideologiczny" tego państwa. Od momentu podpisania tego pakietu przez prezydenta P. Poroszenkę (Poroszenko podpisat, 18.05.2015), wszystko, co sowieckie a nie banderowskie, musi zniknąc z przestrzeni polityczno-historycznej Ukrainy, a wszystko co banderowskie, zostało poddane gloryfikacji i wyniesione na piedestał (Nowopolski, 2015). Co na to polskie elity polityczne? Niestety, w dalszym ciagu są one biernymi obserwatorami nacjonalistycznych przemian na Ukrainie. Przywódcy państwa polskiego nie chcą znać historii. Przyjmą każdą zniewagę narodu polskiego $\mathrm{w}$ imię wyższych, niepolskich interesów. Czasami jednak coś robią. Jak stwierdził wybitny znawca tematu, Andrzej Zapałowski: ,jeżeli Ukraina, będąca w tragicznej sytuacji, robi upokarzające gesty wobec sprzyjającego jej Narodu Polskiego, to należy zadać sobie pytanie, co będzie czyniła w sytuacji odzyskania wewnętrznej stabilizacji. Może się okazać, iż opierając się na tradycyjnym sojuszu nacjonalistów ukraińskich z Niemcami z czasów II wojny światowej, stanie się ona poważnym problemem dla Polski" (Polityka wobec, 2015).

W wyniku uchylenia ustawy językowej, co można uznać za prowokację lub duży błąd wobec rosyjskojęzycznych obywateli Ukrainy, wschód kraju pogrą̇zył się w separatystycznym konflikcie wspomaganym przez imperialną Rosję. Tymczasem nowe władze z premierem Jaceniukiem i wybranym w maju 2014 nowym prezydentem Petrem Poroszenko, dążyły do podpisania umowy stowarzyszeniowej z UE. 21 marca 2014 r. w trakcie kryzysu krymskiego, premier Jaceniuk podpisał w Brukseli część polityczną 
umowy dotyczącą handlu. Z kolei 27 czerwca 2014 roku prezydent Poroszenko podpisał drugą część umowy. Podpisy pod umowami złożyli także liderzy dwóch innych państw: premier Gruzji Irakli Garibaszwilii premier Mołdawii Iurie Leancă z kolei ze strony EU - Herman van Rompuy, przewodniczący Komisji Europejskiej José Manuel Durão Barroso, a także przywódcy 28 krajów UE. W dniu 27 czerwca 2014 roku nowy prezydent Poroszenko podpisał w Brukseli umowę o wolnym handlu z Unią Europejską. 16 września 2014 r. Rada Najwyższa zatwierdziła projekt ustawy o ratyfikacji Układu o stowarzyszeniu między Ukrainą a Unią Europejska, która tego samego dnia została podpisana przez prezydenta Poroszenko. Gabinet Rady Ministrów Ukrainy skierował do Rady Najwyższej projekt ustawy o zniesienie przepisów zabraniających Ukrainie należenia do bloków wojskowych i gospodarczych. W razie wyrażenia przez Ukrainę chęci i spełnienia warunków będzie ona mogła wejść do Sojuszu Północnoatlantyckiego - zapewnił sekretarz generalny NATO Anders Fogh Rasmussen.

21 listopada 2014 roku premier Arsenij Jaceniuk podczas posiedzenia rządu oświadczył, że w związku z decyzją Rady Narodowego Bezpieczeństwa i Obrony (RNBiO), rząd Ukrainy skieruje do parlamentu projekt ustawy o zniesieniu statusu pozablokowego państwa i wystąpi o wznowienie dążenia Ukrainy do członkostwa w NATO. Jak stwierdził premier, ta ustawa pozwoli Ukrainie podejmować decyzje o członkostwie również w innych gospodarczych, politycznych lub wojskowych sojuszach, które nie są sprzeczne z głównym celem Ukrainy - czyli członkostwem w UE. Premier Ukrainy podkreślił, że zwrócił się do parlamentarzystów o natychmiastowe rozpatrzenie projektu ustawy. Całkowicie szanujemy decyzje Ukrainy dotyczące polityki bezpieczeństwa państwa i wyboru sojuszników - skomentował doniesienie sekretarz generalny NATO Anders Fogh Rasmussen. - Nie będę się wtrącał w dyskusje polityczne na Ukrainie, ale pozwólcie mi przypomnieć o ustaleniach szczytu NATO w Bukareszcie z 2008 r. Zgodnie z nimi Ukraina ma możliwość wstąpienia do sojuszu w razie wyrażenia przez nią chęci i spełnienia warunków" - dodał szef Sojuszu Północnoatlantyckiego (Ukraina rozpoczyna, 2014).

UE podpisała w czerwcu gospodarczą część umowy, dotyczącą przede wszystkim wolnego handlu. Jednak wdrożenie umowy handlowej pod naciskiem Rosji odłożono do końca 2015 roku. 16 września Rada Najwyższa Ukrainy oraz Parlament Europejski ratyfikowały umowę stowarzyszeniową. Po głosowaniu Układ obowiązywał tymczasowo - w celu pełnej ratyfikacji umowa musi być ratyfikowana przez wszystkie 28 państw członkowskich Unii. W polskim Sejmie decyzja zapadła niemal jednogłośnie. „Za” głosowało 427 posłów. „Przeciw” był jeden poseł - Roman Kotliński (koło Bezpieczeństwo i Gospodarka; dawniej Ruch Palikota). Natomiast w referendum Holendrzy powiedzieli NIE dla stowarzyszenia Ukrainy w UE.

17. szczyt Ukraina-UE odbył się 27 kwietnia 2015 roku. Poświęcony był reformom ekonomicznym i politycznym oraz kwestii pomocy finansowej UE dla Ukrainy. Odbył się on przy udziale przewodniczącego Rady Europy Donalda Tuska i szefa Komisji Europejskiej Jeana-Claude Junckiera.

Aby stać się członkiem UE, Ukraina musi spełnić kryteria z Kopenhagi - warunki polityczne (stabilny system demokratyczny, praworządność, gwarancje praw mniejszości) i gospodarcze (stworzenie konkurencyjnego rynku). Żaden z tych warunków nie został przez władze i państwo ukraińskie spełniony. 
Jak napisał lwowski publicysta i politolog, Wołodymyr Pawliw: ,ustrojem naszego państwa jest kapitalizm oligarchiczny, z charakterystycznymi dla niego korupcją, niekompetencją, nieodpowiedzialnością, nihilizmem prawnym i licznymi patologiami społecznymi, takimi jak: alkoholizm, narkomania, niska świadomość ekologiczna, problem wykwalifikowanych kadr, a także epidemie "niecywilizowanych" chorób, alkoholizm dziecięcy, przemoc w domu i na ulicach" (Żyszkiewicz, 2015). Przez kilkadziesiąt lat przebywania w ZSRR i dwie dekady niezależności ukraińskiej naród wykształcił specyficzny model homo sovieticusa, który charakteryzuje marazm, świadoma bezczynność i nawet szlachetny zryw demokratów w postaci Euromajdanu nie zmieni tego całościowego oglądu. Jak słusznie zauważył Taras Prochaśko: „Tu ceni się czyny i wysiłki, które nie są związane z pracą nad sobą. Brak prawdziwych pragnień wyklucza strategię, stawiając taktykę na pierwszym miejscu w hierarchii mądrości”. Są to twarde słowa nauczyciela akademickiego i dziennikarza ukraińskiego, wyrzuconego z pracy za stosunek do nacjonalizmu (Żyszkiewicz, 2015).

Droga Ukrainy od sowieckiego feudalnego socjalizmu i banderowskiego totalitaryzmu do demokracji w znaczeniu zachodnioeuropejskim i współczesnej gospodarki rynkowej, aby docelowo wejść do UE i NATO, jest wyjątkowo kręta, niekonsekwentna i zideologizowana. W państwie tym nastapiła:

1) ogromna oligarchizacja gospodarki i życia politycznego;

2) zupełna zapaść funkcji organów państwa;

3) postępująca indoktrynacja społeczeństwa przez ugrupowania nacjonalistyczne;

4) dominacja korupcji we wszystkich dziedzinach życia i szczeblach państwa;

5) bankructwo ekonomiczne na niespotykaną skalę;

6) silny wzrost separatyzmów lokalnych w oparciu o niekompatybilne tradycje historyczne i idee wrogie człowiekowi;

7) państwowe fałszowanie najnowszej historii na wzór rosyjski.

Tak zwana Rewolucja Godności rozpoczęta w Kijowie jesienią 2013 roku, przemieniła się w zacięta walkę oligarchów o podział łupów i wpływów gospodarczo-politycznych. Oligarchia istnieje $\mathrm{w}$ wielu krajach świata. Ale istnieje olbrzymia różnica pomiędzy oligarchą amerykańskim i ukraińskim. Amerykański musi uwzględniać interesy USA, ukraiński uwzględnia tylko swoje. Stąd Kołomojski, Poroszenko, Firtasz czy Achmetow nie są żadnymi równorzędnymi partnerami dla zachodnich rządów. Ktoś, kto świadomie doprowadza do ruiny własny kraj, nie będzie traktowany poważnie w żadnym państwie. Należy w tym miejscu zauważyć, iż PKB Ukrainy jest tej wielkości co PKB Mazowsza z Warszawą, czyli wynosi około 91 mld USD, a Mazowsza 116,4 mld USD z 5,3 miliona mieszkańców (Piechowiak, 2017). Ukraina obok Mołdawii i Albanii jest najbiedniejszym krajem Europy.

Wojna oligarchów i bardzo niestabilna sytuacja w państwie ukraińskim oznacza pogorszenie i tak wyjątkowo niskiej stopy życiowej. Ukraina przeżywa, tak jak i Polska emigrację ludzi młodych, którzy znajdując lepsze warunki życia na Zachodzie nie wrócą na ojcowiznę. Niski poziom życia już powoduje katastrofę humanitarną, a część społeczeństwa cierpi głód.

W państwie ukraińskim swoje interesy rozgrywa Rosja, USA, Niemcy, Izrael i Chiny oraz inni międzynarodowi gracze. Najmocniejsza w tej partii jest Rosja, która 
na Ukrainie posiada wpływy jeszcze sowieckiej prominencji. Włączenie Ukrainy do struktur europejskich i NATO w (nawet w bardzo dalekiej perspektywie czasowej) jest niemożliwe. Finlandyzację Ukrainy proponował prof. Zbigniew Brzeziński, który jeszcze w czasie trwania Majdanu prowokował Ukraińców do walki z Rosja. Podczas spotkania z delegacją z Ukrainy 5 marca 2016 roku minister stanu Krzysztof Szczerski oświadczył, że „Polska jest adwokatem europejskiego wyboru Ukrainy” i opowiedział się za jak najszybszym zniesieniem wiz dla Ukraińców. Ponadto zadeklarował, że „Ukraina będzie obecna podczas szczytu NATO w Warszawie i chcemy, by ta obecność była istotna $\mathrm{i}$ by to posiedzenie rady miało istotne znaczenie dla gwarancji bezpieczeństwa i stabilności w tej części Europy”. Rozwijając tę myśl dodał, że Polska opowiada się za powrotem do Ukrainy Krymu i Donbasu, bo bez tego „nie ma gwarancji pokoju dla Europy". A zatem, zdaniem ministra Szczerskiego, gwarancją pokoju europejskiego jest kontynuowanie wojny w Donbasie, aż do ostatecznego ukraińskiego zwycięstwa (Pietka, 2015). Miarą oderwania od rzeczywistości ministra Szczerskiego jest fakt, iż dwa dni wcześniej przewodniczący Komisji Europejskiej Jean-Claude Juncker oświadczył w Hadze, że „Ukraina z pewnością nie zostanie członkiem Unii w ciągu najbliższych 20-25 lat". Dodał też, że Kijów również nie powinien oczekiwać szybkiego przyjęcia do NATO (Juncker, 2016).

Na odbiór Ukrainy przez społeczeństwa państw UE jednakże największy wpływ ma trudna sytuacja gospodarcza państwa. Próby usprawiedliwiania przez władze w Kijowie tego położenia wojną w Donbasie i trudnościami reorganizacji terytorialnej państwa po aneksji przez Rosję Krymu tylko częściowo usprawiedliwiają obecną sytuację. Można zaryzykować stwierdzenie, że jest to państwo wijące się w konwulsjach, gdzie w pewnych regionach organizacje przestępcze już wyręczają go w monopolu na stosowanie siły. W takim stanie ekonomiczno-prawnym nikt nie weźmie na utrzymanie czterdziestu milionów ludzi, a do tego sprowadzałoby się wstapienie Ukrainy do Unii.

Ukraińska droga do Unii Europejskiej, poprzez wyboje korupcji, oligarchizacji i nachalne szerzenia nacjonalizmu, wiedzie ten kraj, sąsiadujący na przestrzeni $535 \mathrm{~km}$ z Polską, na manowce i margines współczesnej Europy.

\section{Bibliografia}

Barburska O. (2006), Polska wobec europejskich aspiracji Ukrainy, w: Rola Polski w ksztaltowaniu polityki wschodniej Unii Europejskiej na przykładzie Ukrainy, pod red. J. Borkowskiego, Warszawa.

Bielacki J., Lider banderowców: ludobójstwo na Wolyniu to brednia, http://www.rp.pl/arty$\mathrm{kul} / 1083009 . \mathrm{html}$.

Bieleń St. (2014), Rozważania o polskim interesie narodowym, „Stosunki Międzynarodowe”, nr 2 (t. 50).

Brzeziński Z., Ukrajina na szlachu Jewropy, „Ukrajinśke Słowo”, nr 2633.

Czech M., Drugie życie prawdziwych patriotów, portal „Gazety Wyborczej”, http://wyborcza.pl/magazyn/1,135761,15250050,Drugie_zycie_prawdziwych_patriotow.html, 12.12.2014.

Dokumentujemy, żeby pozostał ślad, http://naszdziennik.pl/polska-kraj/185785, dokumentujmy-zeby-pozostal-slad.html, 21.07.2017. 
Dokumenty parlamentarne w sprawie stowarzyszenia UE-Ukraina według stanu na 16.09.2014, Ośrodek Informacji i Dokumentacji Europejskiej, Materiały OIDE, Biblioteka Sejmowa.

25 lat temu 90,92 proc. Ukrainców w referendum potwierdziło niepodległość swojego państwa, http://zik.ua/pl/news/2016/12/01/25_lat_temu_9092_proc_ukraicw_w_referendum_potwierdzio_niepodlego_1001017.

Euratom: Council and Commission Decision of 26 January 1998 on the conclusion of the Partnership and Cooperation Agreement between the European Communities and their Member States, of the one part, and Ukraine, of the other part, eur-lex.europa.eu.

EU-Ukraine Summits: 16 Years of Wheel-Spinning, ukrainianweek.com, 23.02.2013.

Giziński J., Węgrzy ostrożni wobec Ukrainy, „Rzeczpospolita”, http://www.rp.pl/artykul/1090144. $\mathrm{html}$.

Grott B. (2010), Ukraiński nacjonalizm a polska polityka wobec Ukrainy i Ukraińców, „Biuletyn IPN", nr 7-8, http://niniwa22.cba.pl/upa_ukrainski_nacjonalizm.htm.

Haliżak E., Kuźniar R. (2010), Rocznik strategiczny 2008/2009, Warszawa.

Isakowicz-Zaleski T., dla TVN24, http://www.tvn24.pl/wiadomosci-z-kraju,3/jestesmy-naprogu-podzialu-ukrainy-banderowcy-w-rzadzie-to-blad,412809.html.

Juncker J. C. (2016), Ukraina nie wejdzie do Unii w ciagu najbliższych 20-25 lat, www.kresy.pl, 3.03.2016.

Junko J., Oteksandr Turczynow p.o. prezydenta Ukrainy. Anulowana ustawa językowa, „Dziennik Wschodni”, http://www.dziennikwschodni.pl/apps/pbcs.dll/article?AID=/20140223/KRAJSWIAT/140229808, 11.07.2017.

Kamiński S., Sołtyk R., Borrell gani Polske, „Gazeta Wyborcza”, 5.01.2005.

Kapuśniak T. (2007), Wptyw Federacji Rosyjskiej na Ukrainę: instrumenty polityczne i ekonomiczne, Lublin.

Komorowski w gazecie Michnika: „Dla mnie ideałem jest Kościół wolny od wszelkiego zaangażowania politycznego", http://wpolityce.pl/polityka/242992-komorowski-w-gazecie-michnikadla-mnie-idealem-jest-kosciol-wolny-od-wszelkiegozaangazowania-politycznego.

Korniejenko A. (2014), Pelzajaca wojna. Quo vadis, Ukraino?, Kraków.

„Neesweek”, http://swiat.newsweek.pl/wybory-na-ukrainie-2014-oficjalne-wynikinewseek-pl,artykuly,351576,1.html.

Nowopolski I., Balansujac nad ideologicznq przepaściq Ukrainy, http://www.bibula.com/?p=81098.

Olszański T., Ukraines political partie at the start of the election campaign, Ośrodek Studiów Wschodnich.

Olszański T., Rada Najwyższa Ukrainy uchwaliła nowq ustawe językowa, http://www.osw.waw.pl/pl/ publikacje/analizy/2012-07-11/rada-najwyzsza-ukrainy-uchwalila-nowa-ustawe-jezykowa.

Piechowiak Ł., PKB Mazowsza większy od gospodarki Ukrainy, www.bankier.pl/wiadomość/PKBmazowsza-wiekszy-od-gospodarki-Ukrainy-735673.html.

Piętka B., Faszyzacja peryferii, http://www.klubinteligencjipolskiej.p1/2016/04/bohdan-pietka-faszyzacja-peryferii/.

Polityka wobec Ukrainy wymaga weryfikacji, http://www.kresy.pl/publicystyka,wywiady?zobacz/ polityka-wobec-ukrainy-wymaga-weryfikacji.

Poroszenko podpisat ustawę uznającq prawny status bojowników o wolność, w tym członków UPA, http://wiadomosci.wp.pl/kat,1356,title,Poroszenko-podpisal-ustawe-uznajaca-prawny-status-bojownikow-o-wolnosc-w-tym-czlonkow-UPA, wid, 17542779, wiadomosc.html?tica$\mathrm{id}=114 \mathrm{e} 35 \&$ t ticrsn=3, 18.05.2015.

Rychłowski B. (1993), Niepodległość Ukrainy, „Polityka Wschodnia”, nr 1.

Schwertner J., Ivan Kaczanowski: śledztwo ws. „,krwawego czwartku” może uchronić przed wojna, http://pppolsku,blogspot-com/2014/11/Onet-ivan-kacznowski-śledztwo-ws.html. 
Schwertner J., Kto dokonat masakry w Kijowie? Winnicki i Szczerski komentuja badania Kaczanowskiego, http://wiadomosci.onet.pl/tylko-w-onecie/kto-dokonal-masakry-w-kijowie-winnicki-i-szczerski-komentuja-badania-kaczanowskiego/.

Stolarczyk M. (2014), Dylematy bezpieczeństwa Polski w kontekście kryzysu ukraińskiego w latach 2013-2014, w: Dylematy polityki bezpieczeństwa Polski na poczqtku drugiej dekady XXI wieku, red. K. Czornik, M. Lakomy, Katowice.

Witryna internetowa „Swobody”, http://tiahnybok.info/.

Ukraina: koalicja ,Stabilność i Reformy” przejmuje władzę. Azarow nowym premierem, GazetaWyborcza.pl, z 11.03.2010.

Ukraina rozpoczyna drogę do NATO. Pierwsze decyzje zostały podjęte, http://niezalezna.pl/58869ukraina-rozpoczyna-droge-do-nato-pierwsze-decyzje-zostaly-podjete z 26 listopada $2014 \mathrm{r}$.

Zięba R. (2007), Wspólna Polityka Zagraniczna i Bezpieczeństwa Unii Europejskiej, Wydawnictwa Akademickie i Profesjonalne, Warszawa.

Żyszkiewicz W., Jałta 2. Czarny scenariusz, http://waldemar zyszkiewicz.pl/index.php?option= com_content\&task=view\&id=687\&Itemid $=62$.

Żyszkiewicz W., ,,Twarde stowa” ukraińskiego politologa, http://waldemar-zyszkiewicz.pl/index. php?option=com_content\&task=view\&id=719\&Itemid=62.

\section{Streszczenie}

Proklamowanie nowego państwa o nazwie Ukraina w 1991 roku zmieniło sytuację geopolityczną w Europie, ponieważ weszło ono do grona sześciu największych państw kontynentu. Już w 1994 roku Ukraina podpisała z UE układ o partnerstwie i współpracy. W latach 1998-2015 odbyło się piętnaście spotkań Ukraina-UE w celu wejścia tego państwa do struktur europejskich. Mimo niespełnienia przez nie kryteriów kopenhaskich, podpisano umowę stowarzyszeniową, ratyfikowaną przez część państw UE. W wyniku wielu procesów wewnętrznych i realizacji polityki według zasad skrajnych ideologii, Ukraina po ćwierćwieczu istnienia, stała się państwem upadłym, przeżartym przez korupcję, system oligarchiczno-mafijny i ideologię nacjonalizmu. Jest to państwo zagrożone rozpadem swego terytorium lub wejściem w orbitę wpływów Rosji, o co toczy się obecna wojna. Dążenia władz Ukrainy do wejścia w struktury UE są więc całkowicie nierealne i bezprzedmiotowe.

Słowa kluczowe: dążenia Ukrainy do UE, kryteria kopenhaskie, banderyzm, upadek Ukrainy, nacjonalizm

\section{A critical look at the European aspirations of Ukraine and Poland's position}

\section{Summary}

The proclamation of a new state named Ukraine in 1991 changed the geopolitical situation in Europe because it entered the circle of the six largest countries of the continent. Already in 1994 Ukraine signed an agreement with the EU on partnership and cooperation. In the period 1998-2015, 15 meetings of EU and Ukraine on joining the European structures took place. Although the Copenhagen criteria haven't been met, the association agreement was signed and ratified by several EU Member States. As a result of many internal processes and implementation of politics based on extreme ideologies Ukraine, after only 25 years of its existence, became a fallen state riddled with corruption, an oligarchic-mafia system governed by the neoban- 
derism ideology. It is a country endangered by breakup of its territory or entering the orbit of the influence of Russia; this is what the current war is about. Thus, the efforts of the Ukrainian authorities to join the structures of the EU seem to be completely unrealistic and useless.

Key words: the Copenhagen criteria, Banderism, the collapse of Ukraine, nationalism 